\title{
OCENA WPLYWU WARUNKÓW POMIARU NA WYNIKI OZNACZENIA MODUŁU SZTYWNOŚCI BETONU ASFALTOWEGO
}

\begin{abstract}
W artykule przedstawiono wyniki analiz statystycznych dotyczących rezultatów oznaczania modułu sztywności betonu asfaltowego metodą pośredniego rozciągania (IT-CY). Badaniu poddano próbki betonu asfaltowego o wysokim module sztywności zgodnie z procedurą normową. Wykonana analiza potwierdza, że na wartość modułu sztywności znaczący wpływ mają warunki wykonywania pomiaru, w tym przypadku analizowano wartość amplitudy poziomego przemieszczenia. Zmniejszenie docelowej wartości poziomego przemieszczenia, powoduje iż zmniejszeniu ulega także wartość pionowej siły potrzebnej do wykonania pomiaru, co jest przydatne przy badaniach mieszanek o wysokim module sztywności w niskiej temperaturze. Analiza statystyczna uzyskanych wyników wykazała jednak, że wartości modułów sztywności uzyskanych przy różnych przemieszczeniach nie można porównywać bezpośrednio. Na podstawie przeprowadzonego studium literatury w zakresie przyjmowanych współczynników Poissona, wybrano wiarygodną metodę ich określania do stosowania $\mathrm{w}$ metodzie rozciągania pośredniego. Zwrócono także uwagę na ziemność wartości modułu sztywności spowodowaną przyjmowaniem różnych współczynników Poissona.
\end{abstract}

Słowa kluczowe: rozciąganie pośrednie, beton asfaltowy o wysokim module sztywności, współczynnik Poissona, przemieszczenie poziome, moduł sztywności

\section{Wprowadzenie}

Moduł sztywności, zgodnie z definicją podaną w normie PN-EN 1269726:2012 „Mieszanki mineralno-asfaltowe - Metody badań mieszanek mineralno-asfaltowych na gorąco - Część 26: Sztywność" jest to zależność pomiędzy naprężeniem i odkształceniem wyznaczona dla materiału liniowo lepkosprężystego w czasie $t \mathrm{w}$ trybie kontrolowanego przyrostu odkształcenia. Współ-

\footnotetext{
${ }^{1}$ Autor do korespondencji/corresponding author: Mieczysław Słowik, Politechnika Poznańska, Instytut Inżynierii Lądowej, ul. Piotrowo 5, 61-138 Poznań, +48 61665 2478, e-mail: mieczyslaw.slowik@put.poznan.pl

${ }^{2}$ Mikołaj Bartkowiak, Politechnika Poznańska, Instytut Inżynierii Lądowej, ul. Piotrowo 5, 61-138 Poznań, +48 61665 2435, e-mail: mikolaj.bartkowiak@put.poznan.pl
} 
czynnik Poissona można zdefiniować jako stosunek względnego odkształcenia prostopadłego do kierunku rozciągania (lub ściskania) do względnego odkształcenia w kierunku działania siły obciążającej [3]. Wartości wymienionych wielkości są kluczowymi parametrami charakteryzującymi mieszanki mineralno-asfaltowe w procesie projektowania nawierzchni metodami mechanistycznymi. Moduł sztywności jest także brany pod uwagę przy projektowaniu składu mieszanek mineralno-asfaltowych, jako parametr, który w wyniku swej zależności od wielu innych cech materiałowych najbardziej ogólnie charakteryzuje mieszankę. Moduł sztywności jest także istotną wielkością wykorzystywaną do oceny właściwości niskotemperaturowych mieszanek mineralno-asfaltowych.

\section{Badana mieszanka mineralno-asfaltowa}

Mieszanką wykorzystaną do wykonania próbek do badań był beton asfaltowy o wysokim module sztywności (AC WMS 16 PMB 25/55-60) przeznaczony do warstwy wiążącej oraz podbudowy nawierzchni obciążonej ruchem KR 5-6 zaprojektowaną według wymagań podanych w [14]. Próbki walcowe zagęszczano metodą Marshalla według normy PN-EN 12697-30:2012 „Mieszanki mineralno-asfaltowe - Metody badań mieszanek mineralno-asfaltowych na gorąco - Część 30: Przygotowanie próbek zagęszczonych przez ubijanie".

\section{Metodyka badawcza}

\subsection{Oznaczanie modułu sztywności}

Oznaczanie modułu sztywności jest przedmiotem wielu badań, w wyniku których na przestrzeni lat powstało wiele metod oznaczania tej wielkości. W laboratoriach drogowych najczęściej korzysta się z metod oznaczania modułu sztywności opisanych w normie PN-EN 12697-26:2012, ale w publikacjach naukowych opisywane są także inne metody, takie jak np. metoda częstotliwościowa [9]. Zróżnicowanie metod badawczych powoduje, iż przy każdej wartości modułu sztywności powinna być podana metoda jego oznaczenia oraz warunki, w których zostało ono wykonane. Wynika to $\mathrm{z}$ faktu, że mieszanka mineralno-asfaltowa ze względu na wielofrakcyjność materiału mineralnego, jego zróżnicowany skład mineralogiczny oraz zmienność wtaściwości lepiszcza asfaltowego, jest jednym z najbardziej złożonych materiałów budowlanych [12]. Moduł sztywności jak podkreśla się w literaturze [7] jest parametrem a nie stałą, dlatego dokładne określenie warunków badania oraz zależności wartości modułu od tych warunków jest bardzo istotne i powinno być wykonane $\mathrm{z}$ wykorzystaniem uznanych metod statystycznych.

Przedmiotem prezentowanej pracy było wykonanie analizy statystycznej wyników oznaczania modułu sztywności metodą rozciągania pośredniego (ITCY) w różnych temperaturach wg PN-EN 12697-26:2012. Metoda rozciągania 
pośredniego jest jedną z najpopularniejszych metod oznaczania tego parametru. Walcowe próbki do badań, można w łatwy sposób wyciąć z istniejącej nawierzchni bądź przygotować w laboratorium. Łatwość pozyskania próbek z istniejącej nawierzchni powoduje, iż jest to metoda mogąca stanowić badanie kontrolne wykonanej nawierzchni bądź badanie mające określić stan warstw nawierzchni przeznaczonej do przebudowy. Wyniki oznaczeń modułu sztywności należy analizować z dużą ostrożnością, gdyż według [2] [10] [8], zmiana warunków badania, może powodować duże różnice w otrzymywanych wynikach. Różnice te według doświadczeń autorów [11] oraz innych badaczy [8] mogą także wynikać z błędów popełnionych podczas wykonywania oznaczenia.

\subsection{Określenie wartości współczynnika Poissona}

We wzorze umożliwiającym obliczenie modułu sztywności metodą rozciągania pośredniego występuje współczynnik Poissona $v$. Norma PN-EN 1269726:2012 podaje, że jeżeli ten współczynnik nie został wyznaczony, to niezależnie od zastosowanej temperatury pomiaru należy przyjmować wartość $\mathrm{v}=0,35$. W literaturze natomiast można spotkać zróżnicowane wartości współczynnika Poissona $\mathrm{w}$ zależności od temperatury. Po porównaniu współczynników Poissona zamieszczonych w różnych publikacjach [15] [5] [6], autorzy przyjęli wartości obliczone z równania (1) zaproponowanego przez Witczaka i Mirza [13] (tabela 1). Zdecydowano się na takie rozwiązanie, gdyż zostało ono przedstawione jako rezultat dużego programu badawczego NCHRP oraz ze względu na doświadczenie i uznany autorytet autorów równania.

$$
v=0,15+\frac{0,35}{1+\exp [3,1849-0,04233 \cdot T]}
$$

gdzie: $v$ - współczynnik Poissona [-],

$$
T \text { - temperatura }\left[{ }^{\circ} \mathrm{F}\right] \text {. }
$$

Tabela 1. Współczynniki Poissona obliczone wg (1)

Table 1. Poisson's rations calculated from equation (1)

\begin{tabular}{|l|c|c|c|c|c|c|c|c|c|}
\hline Temperatura $\left[{ }^{\circ} \mathrm{C}\right]$ & -10 & -5 & 0 & 2 & 5 & 10 & 15 & 20 & 25 \\
\hline Wsp. Poissona $[-]$ & 0,17 & 0,18 & 0,20 & 0,20 & 0,22 & 0,24 & 0,27 & 0,30 & 0,33 \\
\hline
\end{tabular}

Jeśli współczynnik Poissona nie jest oznaczany przy okazji wyznaczania modułu sztywności metodą rozciągania pośredniego, część badaczy stosuje się do zaleceń normy przyjmując $\mathrm{v}=0,35$, inna część przyjmuje a priori różne wartości w zależności od temperatury badania. Takie zróżnicowanie przyjmowanych wartości może prowadzić do błędu. Na wartość współczynnika Poissona należy zwrócić uwagę również w przypadku porównywania wartości oznaczonych doświadczalnie z wartościami wyznaczonymi z wykorzystaniem wzorów empirycznych. 


\section{Wyniki oznaczania modułu sztywności}

\subsection{Wpływ zadanego przemieszczenia poziomego}

Moduł sztywności oznaczono metodą rozciągania pośredniego (IT-CY) według normy PN-EN 12697-26:2012. Do analizy statystycznej wykorzystano wartości skorygowanego modułu sztywności uzyskane dla ośmiu próbek (16 wyników pomiarów). Uzyskane wartości poddano testom Hampela i Chauveneta oraz testom na normalność rozkładu, metodami opisanymi w [11] [1], w efekcie czego pewna liczba rezultatów została odrzucona jako wartości odbiegające. Po eliminacji wartości odbiegających wszystkie zbiory wyników mają rozkład normalny. Wynik oznaczenia składa się z wartości średniej i niepewności rozszerzonej, obliczonej według [4], z wykorzystaniem rozkładu t-Studenta przy poziomie istotności $\alpha=0,05$.

Norma PN-EN 12697-26:2012 podaje, że docelowe poziome przemieszczenie dla próbek o nominalnej średnicy $\mathrm{d}=100 \mathrm{~mm}$ powinno wynosić $\mathrm{z}=5 \pm 2 \mu \mathrm{m}$. Jednak w niskiej temperaturze badania układ pneumatyczny wykorzystywanego przez autorów urządzenia nie był w stanie wygenerować odpowiedniej siły do uzyskania takiego przemieszczenia. Autorzy z wcześniejszych doświadczeń [11] wnioskują, iż dozwolona tolerancja wartości poziomego przemieszczenia nie powinna być większa niż $\pm 0,2 \mu \mathrm{m}$ zamiast $\pm 2 \mu \mathrm{m}$. Przy tak założonej tolerancji poziomego przemieszczenia w celu zmniejszenia wartości siły pionowej, koniecznej do wykonania oznaczenia, jest możliwe zmniejszenie wymaganej wartości przemieszczenia poziomego do np. $\mathrm{z}=3 \pm 0,2 \mu \mathrm{m}$, co zostało wykonane. Założono, że zmiana zadanego przemieszczenia nie będzie skutkować istotnymi zmianami uzyskanych wyników oznaczenia modułu sztywności. Wyniki oznaczeń modułu sztywności mieszanki badanej w zróżnicowanej temperaturze dla przemieszczenia $\mathrm{z}=5 \pm 0,2 \mu \mathrm{m}$ pokazano $\mathrm{w}$ tabeli 2 i rysunku 1 , a dla przemieszczenia $\mathrm{z}=3 \pm 0,2 \mu \mathrm{m}$ pokazano $\mathrm{w}$ tabeli 3 . Prezentowane $\mathrm{w}$ tej części wyniki zostały oznaczone przy stałej wartości współczynnika Poissona v $=0,35$.

$\mathrm{W}$ temperaturze $5,10,15,20^{\circ} \mathrm{C}$ dokonano oznaczeń przy obu zadanych wartościach przemieszczenia poziomego, a uzyskane wartości poddano testom statystycznym według [4]. Testy dla dwóch wariancji wykazały, iż wariancje rozkładu dla obu przemieszczeń, są jednakowe, a więc można porównywać średnie tych rozkładów. Testy dla dwóch średnich (dla $\mathrm{z}=3 \mu \mathrm{m}$ i dla $\mathrm{z}=5 \mu \mathrm{m}$ ) czterokrotnie wykazały dla analizowanych temperatur, że średnie uzyskane dla różnych przemieszczeń różnią się istotnie. Warto także podkreślić, że we wszystkich czterech analizowanych temperaturach wartość średniej uzyskanej dla przemieszczenia $\mathrm{z}=5 \mu \mathrm{m}$ okazała się mniejsza niż wartość średniej dla przemieszczenia $\mathrm{z}=3 \mu \mathrm{m}$.

Względne różnice pomiędzy średnimi uzyskanymi z pomiarów dla różnych przemieszczeń wynoszą: $4 \%$ dla $5^{\circ} \mathrm{C}, 7 \%$ dla $10^{\circ} \mathrm{C}, 12 \%$ dla $15^{\circ} \mathrm{C}, 11 \%$ dla $20^{\circ} \mathrm{C}$ i są znacząco większe od względnych niepewności rozszerzonych. 
Tabela 2. Wyniki oznaczania modułu sztywności $\mathrm{S}_{\mathrm{m}}$ (IT-CY) dla $\mathrm{z}=5 \mu \mathrm{m}$ i v $=0,35$

Table 2. Results of measured stiffness modulus Sm (IT-CY) for $z=5 \mu \mathrm{m}$ and $v=0,35$

\begin{tabular}{|l|c|c|c|c|c|c|}
\hline Temperatura, $\mathrm{t}\left[{ }^{\circ} \mathrm{C}\right]$ & $\mathbf{2}$ & $\mathbf{5}$ & $\mathbf{1 0}$ & $\mathbf{1 5}$ & $\mathbf{2 0}$ & $\mathbf{2 5}$ \\
\hline Liczebność próby, $\mathrm{n}[-]$ & 16 & 16 & 16 & 15 & 16 & 16 \\
\hline Średnia m( $\left.\mathrm{S}_{\mathrm{m}}\right),[\mathrm{MPa}]$ & 25806 & 22359 & 17267 & 13163 & 9747 & 6972 \\
\hline $\begin{array}{l}\text { Niepewność rozszerzona } \\
\mathrm{U}\left(\mathrm{S}_{\mathrm{m}}\right),[\mathrm{MPa}]\end{array}$ & 902 & 439 & 368 & 287 & 347 & 155 \\
\hline $\begin{array}{l}\text { Względna niepewność } \\
\text { rozszerzona } \mathrm{U}_{\mathrm{r}}\left(\mathrm{S}_{\mathrm{m}}\right),[\%]\end{array}$ & 3 & 2 & 2 & 2 & 4 & 2 \\
\hline
\end{tabular}

Tabela 3. Wyniki oznaczania modułu sztywności $\mathrm{S}_{\mathrm{m}}$ (IT-CY) dla $\mathrm{z}=3 \mu \mathrm{m}$ i v $=0,35$

Table 3. Results of measured stiffness modulus Sm (IT-CY) for $z=3 \mu \mathrm{m}$ and $v=0,35$

\begin{tabular}{|l|c|c|c|c|c|c|c|}
\hline Temperatura, $\mathrm{t}\left[{ }^{\circ} \mathrm{C}\right]$ & $\mathbf{- 1 0}$ & $\mathbf{- 5}$ & $\mathbf{0}$ & $\mathbf{5}$ & $\mathbf{1 0}$ & $\mathbf{1 5}$ & $\mathbf{2 0}$ \\
\hline Liczebność próby, $\mathrm{n}[-]$ & 16 & 16 & 15 & 14 & 16 & 16 & 16 \\
\hline Średnia m( $\left.\mathrm{S}_{\mathrm{m}}\right),[\mathrm{MPa}]$ & 34593 & 30431 & 27350 & 23303 & 18462 & 14763 & 10831 \\
\hline $\begin{array}{l}\text { Niepewność rozszerzo- } \\
\left.\text { na U( } \mathrm{S}_{\mathrm{m}}\right),[\mathrm{MPa}]\end{array}$ & 567 & 467 & 496 & 210 & 410 & 378 & 292 \\
\hline $\begin{array}{l}\text { Względna niepewność } \\
\text { rozszerzona } \mathrm{U}_{\mathrm{r}}\left(\mathrm{S}_{\mathrm{m}}\right),[\%]\end{array}$ & 2 & 2 & 2 & 1 & 2 & 3 & 3 \\
\hline
\end{tabular}

\subsection{Wpływ zróżnicowania wartości współczynnika Poissona}

Porównując wartości modułu sztywności IT-CY uzyskane z różnych źródeł, należy zwrócić także uwagę na współczynnik Poissona. Wyniki oznaczeń dla stałego współczynnika Poissona równego v=0,35, przyjętego według normy PNEN 12697-26:2012, zostały zaprezentowane w tabelach 2 i 3 . W tabelach 4 i 5 pokazano rezultaty tych samych badań przeliczone z uwzględnieniem współczynników Poissona obliczonych według równania Witczaka i Mirzy. Na rysunku 1 graficznie przedstawiono wyniki oznaczania modułów sztywności dla $\mathrm{z}=5 \mu \mathrm{m}$ i różnych współczynników Poissona.

Tabela 4. Wyniki oznaczania modułu sztywności $\mathrm{S}_{\mathrm{m}}$ (IT-CY) dla $\mathrm{z}=5 \mu \mathrm{m}$ i zmiennego $\mathrm{v}$

Table 4. Results of measured stiffness modulus Sm (IT-CY) for $\mathrm{z}=5 \mu \mathrm{m}$ and variable value of $\mathrm{v}$

\begin{tabular}{|l|c|c|c|c|c|c|}
\hline Temperatura, $\mathrm{t}\left[{ }^{\circ} \mathrm{C}\right]$ & $\mathbf{2}$ & $\mathbf{5}$ & $\mathbf{1 0}$ & $\mathbf{1 5}$ & $\mathbf{2 0}$ & $\mathbf{2 5}$ \\
\hline Liczebność próby, $\mathrm{n}[-]$ & 16 & 16 & 16 & 15 & 16 & 16 \\
\hline Wsp. Poissona, v [-] & 0,21 & 0,22 & 0,24 & 0,27 & 0,3 & 0,33 \\
\hline Średnia m( $\left.\mathrm{S}_{\mathrm{m}}\right),[\mathrm{MPa}]$ & 19979 & 17671 & 14203 & 11464 & 8961 & 6747 \\
\hline $\begin{array}{l}\text { Niepewność rozszerzona } \\
\mathrm{U}\left(\mathrm{S}_{\mathrm{m}}\right),[\mathrm{MPa}]\end{array}$ & 698 & 347 & 303 & 250 & 319 & 150 \\
\hline
\end{tabular}


Tabela 5. Wyniki oznaczania modułu sztywności $\mathrm{S}_{\mathrm{m}}$ (IT-CY) dla $\mathrm{z}=3 \mu \mathrm{m}$ i zmiennego $\mathrm{v}$

Table 5. Results of measured stiffness modulus Sm (IT-CY) for $z=3 \mu \mathrm{m}$ and variable value of $\mathrm{v}$

\begin{tabular}{|l|c|c|c|c|c|c|c|}
\hline Temperatura, $\mathrm{t}\left[{ }^{\circ} \mathrm{C}\right]$ & $\mathbf{- 1 0}$ & $\mathbf{- 5}$ & $\mathbf{0}$ & $\mathbf{5}$ & $\mathbf{1 0}$ & $\mathbf{1 5}$ & $\mathbf{2 0}$ \\
\hline Liczebność próby, $\mathrm{n}[-]$ & 16 & 16 & 15 & 14 & 16 & 16 & 16 \\
\hline Wsp. Poissona, v [-] & 0,17 & 0,18 & 0,20 & 0,22 & 0,24 & 0,27 & 0,3 \\
\hline Średnia m( $\left.\mathrm{S}_{\mathrm{m}}\right),[\mathrm{MPa}]$ & 24550 & 22087 & 20733 & 18417 & 15187 & 12858 & 9958 \\
\hline $\begin{array}{l}\text { Niepewność rozszerzona } \\
\mathrm{U}\left(\mathrm{S}_{\mathrm{m}}\right),[\mathrm{MPa}]\end{array}$ & 403 & 339 & 376 & 166 & 338 & 330 & 269 \\
\hline
\end{tabular}

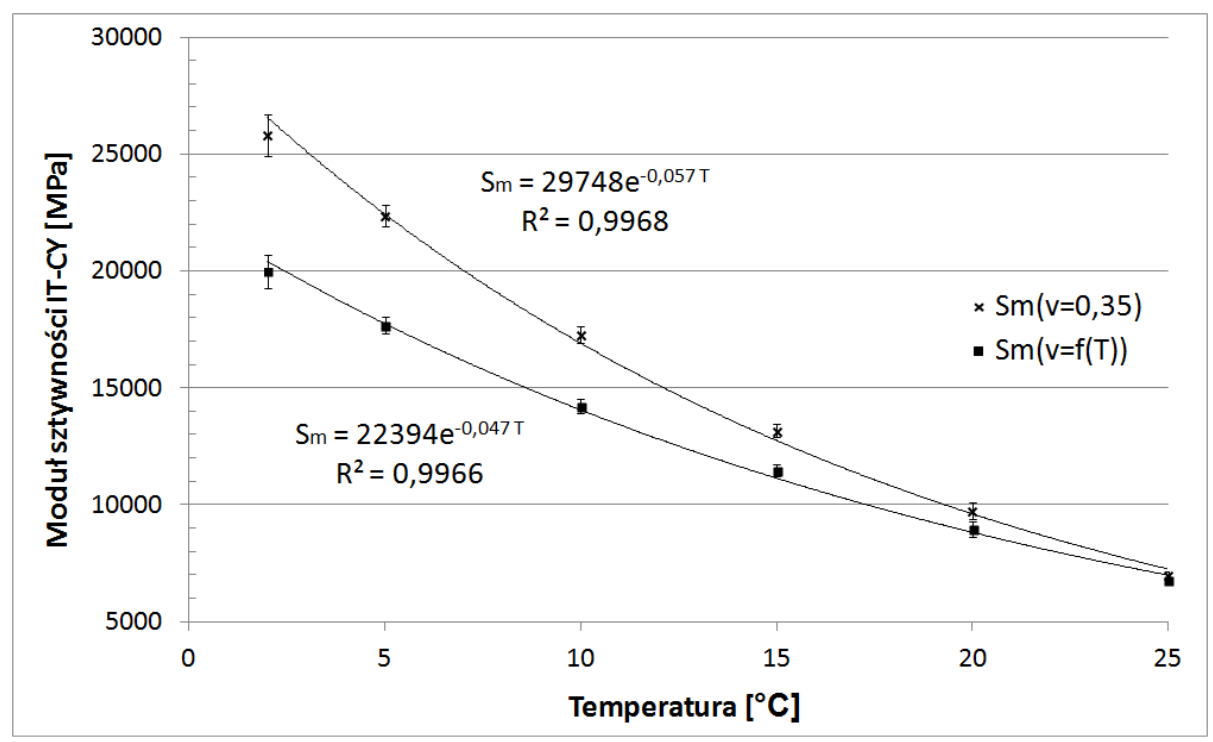

Rys. 1. Wyniki oznaczania modułu sztywności $\mathrm{S}_{\mathrm{m}}$ (IT-CY, $\mathrm{z}=5 \mu \mathrm{m}$ ) dla $\mathrm{v}=0,35$ oraz dla zmiennej wartości $\mathrm{v}$

Fig. 1. Results of measured stiffness modulus $S_{m}(I T-C Y, z=5 \mu \mathrm{m})$ for $v=0,35$ and for variable value of $v$

\section{Wnioski}

Przeprowadzone badania wskazują, że wartość modułu sztywności zależy od warunków przeprowadzania oznaczenia modułu sztywności metodą rozciągania pośredniego (ITCY). Uzyskane wyniki mogą świadczyć o tym, że nawet niewielka zmiana pozornie mało znaczącego parametru jak docelowe przemieszczenie poziome może powodować zmianę uzyskanego modułu sztywności. Dla mniejszej wartości poziomego przemieszczenia otrzymano większe wartości modułu sztywności. Wyniki te potwierdzają wnioski przedstawione w pracy [10]. Zmniejszenie wartości poziomego przemieszczenia do $\mathrm{z}=3 \mu \mathrm{m}$ podczas 
oznaczenia modułu sztywności metodą pośredniego rozciągania (IT-CY) pozwala na wyznaczanie wielkości tego parametru dla mieszanek o wysokich modułach sztywności $\mathrm{w}$ niskiej temperaturze $\mathrm{w}$ standardowym czasie przyrostu siły $(\mathrm{t}=124 \pm 4 \mathrm{~ms})$ jednak oznaczone $\mathrm{w}$ ten sposób wartości modułu sztywności okazały się większe od wartości uzyskanych dla standardowego przemieszczenia $(\mathrm{z}=5 \mu \mathrm{m})$. Względna różnica pomiędzy średnimi uzyskanymi z pomiarów wynosi od 4 do $12 \%$.

Przy porównywaniu wartości modułów sztywności uzyskanych z badań laboratoryjnych, wzorów empirycznych czy wyników zamieszczonych w literaturze należy zwracać szczególną uwagę na wszystkie warunki wykonania badania. Dla badania metodą pośredniego rozciągania istotne są także takie parametry jak współczynnik Poissona i amplituda poziomego przemieszczenia. Przy tak dużym zróżnicowaniu wartości modułu sztywności należy dobrze się zastanowić jaką wartość wybrać do projektowania nawierzchni metodami mechanistycznymi.

\section{Literatura}

[1] Bartkowiak M., Słowik M.: Niepewność pomiaru gęstości objętościowej mieszanki mineralno-asfaltowej, Drogownictwo 11/2015, s. 380-386, Warszawa 2015.

[2] Carbonneau X. and others: Evaluation of the indirect tensile stiffness modulus test, 6th RILIEM Symposium, Zurich 2003.

[3] Encyclopedia PWN część: nauki ścisłe, http://encyklopedia.pwn.pl [dostęp: 12 kwietnia 2016 r.].

[4] Greń J.: Statystyka matematyczna. Modele i zadania., Państwowe Wydawnictwo Naukowe, Warszawa 1984.

[5] Katalog przebudów i remontów nawierzchni podatnych i półsztywnych - wersja robocza, Instytut Badawczy Dróg i Mostów, Warszawa 2013.

[6] Katalog wzmocnień i remontów nawierzchni podatnych i półsztywnych, Instytut Badawczy Dróg i Mostów, Warszawa 2001.

[7] Kim R. Y.: Modeling of asphalt concrete, McGraw-Hill Construction, Washington 2009.

[8] Międzylaboratoryjne badania modułu sztywności sprężystej metodą rozciągania pośredniego (IT-CY) zgodnie z PN-EN 12697-26 - sprawozdanie, Instytut Badawczy Dróg i Mostów, Warszawa 2006.

[9] Ryden N.: Determining the asphalt mastercurve from free resonant testing on cylindrical samples, Non-Destructive Testing in Civil Engineering, Nantes 2009.

[10] Shalaby A., Liske T. and Kavussi A.: Comparing back-calculated and laboratory resilient moduli of bituminous paving mixture, Canadian Journal of Civil Engineering, Vol. 31, p. 988-996, 2004.

[11] Słowik M., Bartkowiak M.: Calculation of Measurement Uncertainty for Stiffness Modulus of Asphalt Mixture, Journal of Civil Engineering and Architecture vol. 9, number 11, p.1325-1333, November 2015.

[12] Stefańczyk B., Mieczkowski P.: Mieszanki mineralno-asfaltowe. Wykonawstwo i badania., Wydawnictwa Komunikacji i Łączności, Warszawa 2009.

[13] Witczak M. W.: Simple performance test for superpave mix design, NCHRP report 465, Washington 2002. 
[14] Wymagania techniczne WT-2, Nawierzchnie asfaltowe na drogach krajowych, Generalna Dyrekcja Dróg Krajowych i Autostrad, Warszawa 2010.

[15] Zak J. and others: Poisson's ratio of hot asphalt mixtures determined by relaxation and small amplitude oscillation test, Journal of Testing and Evaluation, June 2014.

\section{ASSESSMENT OF TEST CONDITIONS IMPACT ON THE RESULTS OF ASPHALT CONCRETE STIFFNESS MODULUS}

\section{S u m m a r y}

The article presents the results of statistical analyzes concerning values of stiffness modulus of asphalt concrete. The stiffness modulus was examined by indirect tensile test (IT-CY) carried out using cylindrical specimens. The specimens were made from high modulus asphalt concrete (HMAC). The tests were conducted according to European Standard EN 12697-26:2012. The analysis confirms that the values of stiffness modulus depend on conditions of the tests. In presented paper authors analyzed the impact of horizontal displacement on the value of stiffness modulus. The reduction in amplitude of horizontal displacement leads to reduction of the value of applied vertical load. This slide is advantageous for measuring the stiffness of HMAC at low temperatures. Statistical analysis of the results showed that the values of stiffness modulus obtained for the different displacement cannot be compared directly. The article present values of Poisson's ratio, which was accepted by the authors after literature review.

Keywords: indirect tensile test, high modulus asphalt concrete, Poisson's ratio, horizontal displacement, stiffness modulus

Przestano do redakcji: 07.06.2016 $r$.

Przyjęto do druku: 30.06.2016 r.

DOI: $10.7862 / \mathrm{rb} .2016 .88$ 